福岡市とその近郊の中学生及び大学生（年齢12，13歳及び18，19歳）

の体組成と有酸素能力の関係

池田 修 1)・高崎裕治 2)・安河内 朗 2)

1) 福岡教育大学・体育研究センター

2) 九州芸術工科大学・人間工学教室

要約 福岡市及びその近郊に居住する中学生と大学生の男女の身長, 体重, 皮下脂肪厚の 測定並びに最大下作業による最大酸素摄取量の推定を実施した。身長, 体重, 脂肪比率, 除 脂肪量, 最大酸素摄取量にはそれぞれ有意な性差, 年齢差がみられたが, それらの差は特に 大学生の男女間や男子の中学生と大学生間に著しかった。しかし, 最大酸素摄取量の除脂肪 量に対する回帰直線に性差, 年噛差は認められず, $\mathrm{Y}=-0.012+0.055 \mathrm{X}$ と算出された。 他研究者による報告資料と比較した結果, 福岡にみられる上記回帰直線は鍛練者群を除くす べての地区の被検者に関しての一般的傾向を示すと考えられた。

序論

人の身体的作業容量を評価するのに最大酸素摄取量 が信頼し得る測度となっているととは広く知られてい る。この最大酸素掑取量は体重や体組成としての除脂 肪量之密接な相関関係にある（BUSKIRK \& TAYLOR, 1957; WELCH et al., 1958; DAVIES, 1972; DAVIES et al., 1973)。また最大酸素摄取量には年齢, 性別, 人種などにより相違が見られる (̊̊STRAND, 1956; IKAI et al., 1970)。本研究は福岡の中学生之 大学生 (年齢 12,13 歳及び 18,19 歳) の体組成及び有 酸素能力の特徴之両者の関係を明ら加严ることを目 的とするあのである。

\section{方法}

福岡市及びその近郊に居住する健康な中学生と大学 生を被検者とし, 身長, 体重, 皮下脂肪厚の計測とス テップワークを実施した。被検者は福岡教育大学附属 中学校の 12,13 歳の男子生徒38名, 女子生徒 29 名, ま た福岡教育大学の 18,19 歳の男子学生 31 名, 女子学生 40 名の合計 138 名である。皮下脂肪厚は栄研式皮脂厚 計を使用し, 上腕背部之肩甲骨下部の 2 部位を計測し た。乙れらの計測値から NAGAMINE \& SUZUKI （1964）及び KEYS \& BROŽEK（1953）の式を使用 し脂肪比率を算出した。ステップワークでは台高が男 子 $40 \mathrm{~cm}$, 女子 $30 \mathrm{~cm}$, 昇降頻度は男女之も毎分 25 回 とした。作業の継続時間は 6 分間で最後の 1 分間の心 電図記録と呼気ガス採取を行った。心電図は胸部誘導 により記録し，てれから毎分心拍数を求めた。呼気ガ スはダグラスバッグ法で採取し, ガスサンプルをショ
ランダー微量ガス分析装置またはレスピライザー(フ クダ医理化製)で分析し運動時酸素摄取量を求めた。 得られた心拍数之酸素摄取量からノモグラム（佐藤・ 坂手・高崎, 1976; 佐藤・山崎・津田, 1976) により 各被検者の最大酸素摄取量を推定した。

\section{結果と考察}

福岡地区の被検者の身長, 体重, 脂肪比率, 除脂肪 量, 最大酸素摄取量, 単位体重当り及び単位除脂肪量 当り最大酸素摄取量の平均値と標準偏差を表 1 亿示し た。各測定值について, 大学生と中学生における性差 及び年龄差の有意性を表 2 亿まとめた。

男子中学生の身長は女子中学生より有意倍い值で あったが, 体重に有意な性差は認められなかった。除 脂肪量では有意に中学生男子が女子を上回っており, 中学生においては体重より体組成により早く性差の出 現するととが認められる。大学生と中学生について, 除脂肪量は男子で $17.7 \mathrm{~kg}$, 女子で $4.8 \mathrm{~kg}$ の差を示し 各々大学生が有意に高い值であった。大学生と中学生 の体重差は男子では大半が除脂肪量であったが，女子 では約50\%が脂肪量であった。

体重当り最大酸素摂取量では, 男子の中学生と大学 生の間に有意な差が認められなかったが，女子では大 学生が中学生より有意に少なく年齢差がみられた。性 差については中学生で認められず，大学生では男子が

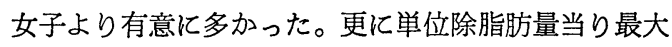
酸素摄取量を中学生, 大学生及び男女間で比較すると 総べての間に有意差がみられなかった。

中学生, 大学生の男女の各被検者群汸ける体重と 
Table 1. Anthropometric and physiological

\begin{tabular}{lccccc}
\hline & $\begin{array}{c}\text { Age } \\
\text { yr. }\end{array}$ & $\begin{array}{c}\text { Subjects } \\
\text { N }\end{array}$ & $\begin{array}{c}\text { Height } \\
\text { cm }\end{array}$ & $\begin{array}{c}\text { Weight } \\
\text { kg }\end{array}$ & $\begin{array}{c}\text { Body Fat } \\
\%\end{array}$ \\
\hline School boy & $12-13$ & 38 & $154.1(8.4)$ & $43.8(7.8)$ & $11.7(2.2)$ \\
College male & $18-19$ & 31 & $170.4(5.6)$ & $62.7(5.9)$ & $10.1(1.7)$ \\
School girl & $12-13$ & 29 & $151.0(5.5)$ & $41.7(6.4)$ & $15.0(3.7)$ \\
College female & $18-19$ & 40 & $156.9(4.5)$ & $51.8(5.3)$ & $22.5(3.0)$ \\
\hline
\end{tabular}

Values are means and (S.D.)

Table 2. T-test of sex difference and age difference on physical characteristics of by subtracting females' from males' in upper two lines and school childrens' from

\begin{tabular}{clcccc}
\hline & Group & $\begin{array}{c}\text { Height } \\
\mathrm{cm}\end{array}$ & $\begin{array}{c}\text { Weight } \\
\mathrm{kg}\end{array}$ & $\begin{array}{c}\text { Body fat } \\
\%\end{array}$ & $\begin{array}{c}\text { L. B. M. } \\
\mathrm{kg}\end{array}$ \\
\hline \multirow{2}{*}{ Sex } & School children & $3.1^{*}$ & 2.1 & $-3.3^{* *}$ & $3.3^{*}$ \\
& College students & $13.5^{* *}$ & $10.9^{* *}$ & $-12.4^{* *}$ & $16.2^{* *}$ \\
& Male subjects & $16.3^{* *}$ & $18.9^{* *}$ & $-1.6^{* *}$ & $17.7^{* *}$ \\
\hline
\end{tabular}

$*$ and $* *$ show the significance at $5 \%$ and $1 \%$ level, respectively.

Table 3. Regression equations of maximal oxygen uptake on body weight for each group in Fukuoka.

\begin{tabular}{lccc}
\hline & $\mathrm{N}$ & $\mathbf{r}$ & Regression equations \\
\hline School boy & 38 & $0.737^{* * *}$ & $\mathrm{Y}=0.377+0.039 \mathrm{X}$ \\
College male & 31 & $0.512^{* * *}$ & $\mathrm{Y}=-0.470+0.057 \mathrm{X}$ \\
School girl & 29 & $0.683^{* * *}$ & $\mathrm{Y}=0.393+0.038 \mathrm{X}$ \\
College female & 40 & $0.589^{* * *}$ & $\mathrm{Y}=-0.300+0.049 \mathrm{X}$ \\
\hline
\end{tabular}

*** shows the significance at $0.1 \%$ level.

Table 4. Regression equations of maximal oxygen uptake on lean body mass for each group in Fukuoka.

\begin{tabular}{lllr}
\hline & $\mathrm{N}$ & \multicolumn{1}{c}{$\mathbf{r}$} & Regression equations \\
\hline School boy & 38 & $0.776^{* * *}$ & $\mathrm{Y}=0.172+0.050 \mathrm{X}$ \\
College male & 31 & $0.529^{* *}$ & $\mathrm{Y}=-0.671+0.067 \mathrm{X}$ \\
School girl & 29 & $0.679^{* * *}$ & $\mathrm{Y}=0.039+0.054 \mathrm{X}$ \\
College female & 40 & $0.600^{* * *}$ & $\mathrm{Y}=-0.153+0.060 \mathrm{X}$ \\
\hline
\end{tabular}

** and *** show the significance at $1 \%$ and $0.1 \%$ level, respectively.

最大酸素摄取量の相関係数は総べて有意となり, 体重 に対する最大酸素摄取量の回帰直線を求めた（表 3 )。 各被検者群の回帰係数の大きさについて共分散分析に より検定すると $\mathrm{F}=0.69$ となり有意な差は認められ
なかったが，直線の高さには有意差（F=4.61, $\mathrm{P}<$ 0.01）のあるととが確かめられた。回帰直線の高さは 男子大学生, 男子中学生, 女子中学生, 女子大学生の 順に低くなった。 
characteristics of subjects in Fukuoka.

\begin{tabular}{|c|c|c|c|}
\hline$\underset{\text { Lg. }}{\text { L. M. }}$ & $\begin{array}{l}\dot{\mathrm{V}}_{\mathrm{O}_{2} \max } \\
\mathrm{l} / \mathrm{min} .\end{array}$ & $\begin{array}{l}\dot{\mathrm{V}}_{\mathrm{o}_{2} \max } / \mathrm{B} . \mathrm{W} \\
\mathrm{ml} / \mathrm{kg} / \mathrm{min} .\end{array}$ & $\begin{array}{l}\dot{\mathrm{V}}_{\mathrm{o}_{2} \max } / \mathrm{L} . \mathrm{B} . \mathrm{M} \\
\mathrm{ml} / \mathrm{kg} / \mathrm{min} .\end{array}$ \\
\hline $38.6(6.5)$ & $2.09(0.42)$ & $47.8(6.6)$ & $54.1(6.9)$ \\
\hline $56.3(5.2)$ & $3.10(0.66)$ & $49.4(8.8)$ & $55.0(6.9)$ \\
\hline $35.3(4.4)$ & $1.96(0.35)$ & $47.1(6.4)$ & $55.5(8.7)$ \\
\hline $40.1(4.5)$ & $2.25(0.45)$ & $43.4(6.9)$ & $56.2(8.7)$ \\
\hline
\end{tabular}

subjects. Values are differences of means obtained students' in lower two lines.

\begin{tabular}{ccc}
\hline $\begin{array}{c}\dot{\mathrm{V}}_{\mathrm{o}_{2} \max } \\
1 / \min \end{array}$ & $\begin{array}{c}\dot{\mathrm{V}}_{\mathrm{o}_{2} \max } / \mathrm{B} . \mathrm{W} . \\
\mathrm{ml} / \mathrm{kg} / \mathrm{min}\end{array}$ & $\begin{array}{c}\dot{\mathrm{V}}_{\mathrm{o}_{2} \max } / \mathrm{L} . \mathrm{B} . \mathrm{M} . \\
\mathrm{ml} / \mathrm{kg} / \mathrm{min}\end{array}$ \\
\hline 0.13 & 0.7 & -1.4 \\
$0.85^{* *}$ & $6.0^{* *}$ & -1.2 \\
$1.01^{* *}$ & 1.6 & 0.9 \\
$0.29^{* *}$ & $-3.7^{*}$ & 0.7 \\
\hline
\end{tabular}

最大酸素摄取量の体重に対する直線性は除脂肪量に 対してもみられた（表 4)。性と年齢群によって分類 した 4 群の回帰直線間の有意差が回帰係数及び直線の

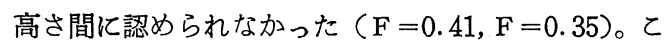
れは除脂肪量が等しければ最大酸素摄取量は性差, 年 龄差に関係なく一定值となることを意味し, 最大酸素 摄取量にみられる個人差は除脂肪量の多少により大部 分あたらされているものと考えられる。福岡の全被検 者における最大酸素摄取量の除脂肪量に対する回帰直 線を求めると,

$$
\widehat{\mathrm{Y}}=-0.012+0.055 \mathrm{X} \quad(\mathrm{r}=0.811, \mathrm{P}<0.001)
$$

となる。本調查と被検者の年齢, 測定項目関して類 似した研究として山崎ら（1977）の名瀬, 坂手(1976) の福山, 亀井ら (1972) の名古屋, 吉沢 (1972) の宇 都宮及び那須が知られている。てれらのうち除脂肪量 が明らかにされてないあのは SENDROY (1966)の身 体容積推定式を用いててれを算出し, 福岡の学生, 生 徒により求めた回帰直線ととあに上記諸研究の示す最 大酸素摄取量之除脂眆量との值を図 1 亿記した。坂手 （1976）を除いて各平均値は福岡の回帰式の95\%信頼 限界の内部またはその周辺に位置した。坂手(1976)の 大学生男女の最大酸素摄取量は顕著に高い值であった が，乙れは資料の対象となる被検者群が体育専攻学生 であるための結果と思われる。BUSKIRK \& TAYLOR （1957）は除脂肪量に対する最大酸素摄取量の回帰関
係がフットボール選手と一般学生で異なるととを報告 しているが，除脂肪量とは別に身体トレーニングの程 度も最大酸素摄取量に影響するととを同様に示唆する 結果と考えられる。福岡の回帰式は特別な身体トレー ニングを行なっていない被検者群に関しての一般的傾 向を示しているといえる。

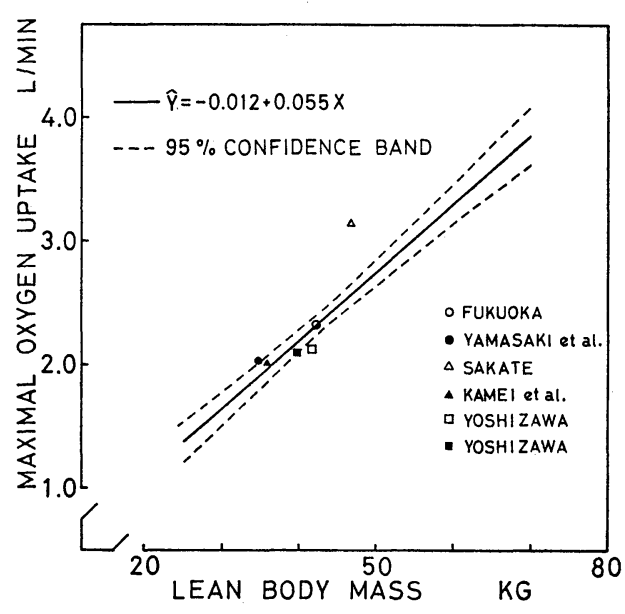

Fig. 1. Regression line of maximal oxygen uptake on lean body mass for all subjects in Fukuoka district. Mean values of Fukuoka and other districts are also indicated. 


\section{文献}

Åstrand, P. O., 1956: Human physical fitness with special reference to sex and age. Physiol. Rev., 36 ; 307-335.

BUSKIRK,E. and H.L. TAYLOR, 1957: Maximal oxygen intake and its relation to body composition, with special reference to chronic physical activity and obesity. J. Appl. Physiol., 11: 72-78.

DAvies, C. T. M., 1972: Maximal aerobic power in relation to body composition in healthy, sedentary adults. Human Biol., 44: 127-139.

Davies, C. T. M., D. Mbelwa, G. Crockford and J.S. WEINER, 1973: Exercise tolerance and body composition of male and female Africans aged 18-30 years. Human Biol., 45: 31-40.

IKAI, M., M. Shindo and M. MiYamura, 1970: Aerobic work capacity of Japanese people. Research J. Physical Education, 14: 135-140. 龟井貞次 - 松井秀治 - 宮下充正 - 水谷四朗 - 星川保 豊島進太郎, $1972 ：$ 青少年にみられる最大酸素摄取 量と体重との関係. 体力科学, $21: 136-142$.

KEYS, A. and J. BROŽEK, 1953: Body fat in adult man. Physiol. Rev., 33: 245-325.
NAGamine, S. and S. SuZUKr, 1964: Anthropometry and body composition of Japanese young men and women. Human Biol., 36:815.

佐藤方彦・坂手照憲・高崎裕治, 1976 ：気温 $20^{\circ} \mathrm{C}$, $30^{\circ} \mathrm{C}$ ，および $40^{\circ} \mathrm{C}$ における最大酸素摄取量推定ノ モグラムの適用. 人類誌, $84: 121-130$.

佐藤方彦・津田隆志・山崎和彦, 1976：気温条件を考 慮した身体的作業容量推定ノモグラム（女性用）の 試作. 人類誌, $84: 259-265$.

Sendroy, J., Jr. and H. A. Collison, 1966: Determination of human body volume from height and weight. J. Appl. Physiol., 21: 167172.

WelCh, B. E., R. P. RIENDEAU, C. E. CRISP and R.S. ISENSTEIN, 1958: Relationship of maximal oxygen consumption to various components of body composition. J. Appl. Physiol., 12: 395-398.

山崎昌広・高崎裕治・坂手照憲・佐藤方彦, 1977 : 奄 美大島の小・中学生の体力調查 (予報). 人類誌, $86: 131-132$.

吉沢茂弘, 1972 : 都市と農村青少年の有酸素的作業能 に関する研究. 体力科学, $21: 161-175$.

(1978年 3 月 20 日受付)

\title{
The Relations between Body Composition and Aerobic Work Capacity in Fukuoka Residents Aged 12, 13 and 18, 19 Years
}

\author{
Osamu IKedA ${ }^{1)}$, Yuji TAKASAKI ${ }^{2)}$ and Akira YASUkouchi ${ }^{2)}$ \\ 1) Research Center of Physical Culture, Fukuoka University of Education \\ 2) Department of Ergonomics, Kyushu Institute for Design Research
}

The estimated maximal oxygen uptake and some indices of body size and composition, including body height, weight, and skinfold thickness at two sites have been determined on subjects aged 12,13 and 18, 19 in Fukuoka during step work. Sex difference in maximal oxygen uptake in aged 18, 19 groups and age difference in body fat percent of weight in females were shown significantly. There were different regression equations of maximal oxygen uptake on body weight with respect to the elevations among age, sex, and region. It is considered partly due to difference in effective muscle mass that can be used to perform the work. On the other hand, the same regression line of maximal oxygen uptake on lean body mass were obtained regardless of sex and age, and it was calculated at $\mathrm{Y}=-0.012+$ $0.055 \mathrm{X}$. As a result, it esems that in relative sedentary residents irrespective of sex, age and region maximal oxygen uptake is related to the volume of lean body mass. 